\title{
Bartholin Gland Squamous Cell
}

\section{Carcinoma}

National Cancer Institute

\section{Source}

National Cancer Institute. Bartholin Gland Squamous Cell Carcinoma. NCI Thesaurus.

Code C40293.

A carcinoma that arises from the Bartholin gland and is characterized by the presence of malignant squamous epithelial cells. 